\title{
ADMINISTRATIVE PROCEEDING RELATIONS IN THE SUBJECT OF ADMINISTRATIVE LAW
}

Article investigates the administrative procedural relations which exist in sphere of action of administrative courts. The place of these establishes the relations in administrative law of Ukraine. For this purpose author investigates the legal nature of norms of administrative legal proceedings; analyzes the legislation on administrative courts; considers practice of work of administrative courts; studies history of administrative judicial system; analyzes scientific research in the sphere administrative law, administrative process, functioning of judicial system; studies drafts of normative documents in the sphere of administrative legal proceedings. As a result of the research author proposed definition of the administrative process.

Key words: administrative court, administrative jurisdiction, administrative law, administrative legal proceedings, administrative process, legal process, procedural relations, public administration.

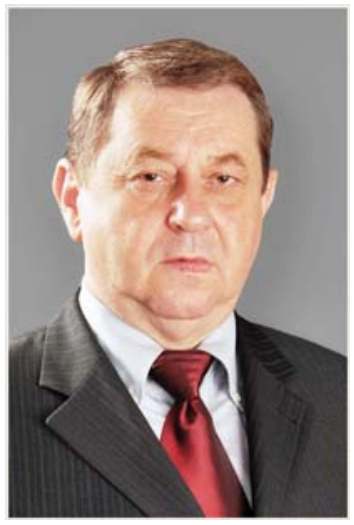

Kolpakov

Valerii Kostiantynovych, Head of the Department of Administrative and Economic Law of the Zaporizhzhia National University, Doctor of Law, Professor

\section{Introduction}

Implementation of Ukrainian administrative procedure in the legal space was one of the most significant achievements of scientific research and law-making for all the years of its independence. This event is the realization of the objective needs of a democratic society to protect the rights of citizens in cases of it's breach by public administration. Functioning of separate judicial administrative jurisdiction is provided by the Law of Ukraine "On ratification of the European Convention on Human Rights in 1950, the First Protocol and Protocols number 2, 4, 7 and 11 of the Convention" on 17 July 1997 (Vidomosti Verkhovnoi Rady Ukrainy, 1997) and the Code of administrative legal proceedings of Ukraine (Vidomosti Verkhovnoi Rady Ukrainy, 2005).

Theoretical understanding of administrative proceeding relations has passed several stages, that have formed modern scientific understanding of their concepts, substantive and functional components, terminology and regulatory definitions. An important feature of this process is it's substantive interdependence with transformation of the subject of administrative law, new understanding of basic administrative and legal categories. As a result, a number of important issues of administrative proceedings development have emerged: regarding control activities of public administration, admin- 
istrative delicts area, administrative services, administrative process and administrative procedures.

There are several approaches as to definition of administrative proceedings: a) a new branch of national procedural law; b) administrative proceedings that may not coincide with administrative process; c) administrative proceeding is an administrative process; d) administrative proceedings is a legal administrative process; e) administrative proceeding is an institute of administrative law.

In our opinion, their definitions largely depend on determining the place of administrative justice in the subject of administrative law. There is still existing managerial understanding of the subject of administrative law, it's basic parameters had been formed during the Soviet Union times, unfortunately not leaving any place for the proceedings in administrative law, or considering it as a part of control activities by public administration.

\section{The subject of administrative law}

Updated modern approach to the subject of administrative law contrarily opens fruitful spheres of scientific research regarding the nature of administrative proceedings. It is based on two main theoretical conclusions, that had been made during development of ideas of the Concept of administrative reform in Ukraine. Firstly, it was based of the conclusion, that administrative law cannot develop a mono-centric structure, like the one, having a single regulatory \& system-developing center (Averianov, 1998). Secondly, the conclusion, that administrative law is a poli-structural law (Kolpakov, 1999). An important role has played the perception of Ukrainian administrative law scientists, considering it's subject to be an important component of it's system-object relations, that arise upon initiative of the parties (Kolpakov, 1999). It had been introduced into the national administrative legal theory as reordinated relations.

Based on these achievements, the concept of the subject of administrative law became broader and incudes the public administration sector, public law regulation, ensuring functioning of public administration. Such a regulation encompasses: a) public administration; b) administrative services; c) responsibility of the society (individual and collective) for violation of the public order and administration regulations or administrative tort relations; d) relations, resulting from the mutual respect of administrative law subjects, that are not related to public authority; e) the relationship of public administration responsibility for the wrongful acts or omissions, resulting from the review of it's decisions. Appeals against decisions of public administration may be carried out either by filing administrative complaints or by judicial review (appeals to the administrative court).

The central issue of the understanding of administrative law subject may be explained by the number of it's components \& integrative quality. It's fundamental importance is due to the fact, that the lack of such a quality resulted into a conglomerate formation. Their unity is only a technical one. The presence of integrative quality proves that the system is a whole, so it may be considered as a subject area of law.

In this respect it should be noted, that in the Soviet legal doctrine of administrative law, the subject was defined a system formation. Integrative nature of the interaction of it's components researchers had argued on the basis of the following 
characteristics: a) all relations belong to the subject, the same types of relations; b) all relations within the subject are relations of power and subordination; c) all object relationships resulting from the implementation of governance are strictly defined structures - public administrations.

At the same time, it is necessary to remember, that the above-mentioned approach didn't have significant support of the researches in the field. In this respect, we'd like to mention the approaches by: Yampolsky, according to it administrative law had not aimed to form a coherent structure across it's subject (Yampol'skaya, 1956); Mrevlishvili, who argued that administrative law is not an independent branch and has no subject (Sovetskoe gosudarstvo i pravo, 1958); Petrov, who highlighted relations between citizens, for example, drivers of the mutual observance of traffic rules (Petrov, 1959).

None of the above integrative features is considered as a new structural component of the subject of modern Ukrainian administrative law. We also cannot include administrative services and responsibility proceedings as the same type of relationship. They also don't include relations of power and subordination. Not all of the updated object relations arise from the implementation of public administration.

There is a set of relationships that is governed by administrative law in the updated terms, converted into the system. These are categories of "public administration" and "administrative actions".

\section{The theory of public administration}

"Public administration" has already taken it's place, that belonged to the category of "state administration" in Soviet administrative law. Today the scientific understanding and further development of the theory of public administration is one of the main areas of doctrinal development of administrative law of Ukraine. It's an important basis of it's transformation into a modern European legal area.

This is not a simple change of terms, the theory of public administration has fundamental differences from the theory of governance: the legal content and ideological nature.

It's formation and recognition puts an end to attempts to adapt the theory of governance to the doctrine of a legal, democratic state - states, where the regulatory power recognizes it's responsibility before the citizen, where human rights and their guarantees determine the content and direction of the state.

Public administration in administrative law of the European countries, in most cases, is defined as a set of authorities and institutions that exercise public authority by enforcing the law, regulations and other actions in the public interest. This is important for the Ukrainian legal system.

It should also be noted, that the concept of public administration is not a new one for the Ukrainian law. It was described in scientific works of Ukrainian researchers in administrative law, who represented the Soviet law school, for example, in the writings of Y.L. Paneyko, who in "Theoretical Foundations of Government" (1963) wrote, that the basis of administrative law regulates the organization and functioning of public administration.

Public administration as a legal category has two dimensions: functional and organizational-structural. According to the functional approach it is an activity of it's structural 
elements to perform functions aimed to implement the public interest. Such an interest in the Ukrainian law is considered as the interest of social community. Thus, for example, the performance of law-enforcement functions of public administration system means that the activities of all structural elements possess this feature. Such an activity had been proposed to be denoted (2009) by the term "public administration".

According to organizational and structural approach public administration is considered to be a collection of bodies, formed to implement public authority. The Ukrainian authorities recognized by public law are: a) the power of the people as a direct democracy; b) governance - legislative, executive, judicial branches; c) local self-government bodies (Pohorilko, 2003).

It means that public power in Ukraine is engaged in the following structures: firstly, the Verkhovna Rada of Ukraine (the Parliament), the President of Ukraine, the local self-government bodies. They realize the power of the people, reflected during elections; secondly, all the authorities and institutions that implement state power. For example, the executive authorities, courts and others; thirdly, all the agencies and institutions that implement the local government. For example, the executive committees of local councils, associations, BSP and so on.

Thus, public administration is a system of organizational and structural formations lawfully acquired powers to implement them in the public interest.

All this makes it necessary to consider the theory of public administration as a methodological basis of administrative law concept and use it as a base to build administrative and legal relations, including relations and administrative proceedings.

Another system-subject to administrative law factor is the category of "relationships administrative obligations". The essence of this relationship due to the content of the Constitution of Ukraine is concerning the responsibility of the state to the individual, recognizing the main duty of the state to affirm and ensure human rights and freedoms, rule of law limiting the powers and actions of public administration by the Constitution and laws of Ukraine.

They imply that the formation of public administration undertakes to meet the interests of society and citizens. Among them there is the obligation of public nature, the implementation of which requires the use of a public administration authority. During their implementation there are relations that have been proposed (2008) to be described as "administrative obligations relationships".

They - the relationship that fulfill administrative obligations of public administration to the public - are the subject of administrative and legal regulations, or subject to administrative law.

This category - administrative obligation relationships - combined four types of relationships, all of which are part of the subject of administrative law. This relationships are: public administration; Relations Administrative Services; relations responsibilities of public administration for the wrongful acts or omissions; relationship of social responsibility (individual and collective) for violation of the public administration and rules of procedure (Kolpakov, 2008).

A characteristic feature of all the above types of administrative legal relations is that public administration bodies act in their ruling party that exercises its executive 
and administrative powers. That has the right to make powerful (mandatory) solution (Kolpakov, 2017).

An important factor regarding the systematization of relations governed by administrative law is public administration. Public administration is an active subject fulfilling the public administration authority. It is made through the use of management, administrative services, participation in relations of subjects of public administration, enforcement for violation of rules established by the public administration.

\section{The principles, methods and forms of public administration}

Public administration is carried out according to the principles, which are divided into: a) the general principles of public administration inherent in all kinds of activities and b) the special principles of public administration.

Special principles inherent to specific types of administration: public administration; provision of administrative services; the establishment and implementation of public administration responsibility for violation of positive human society; the establishment and implementation of social responsibility for the violation of public administration standards.

Adherence to the principles of public administration regulation provided methods and forms of public administration. According to the principles, methods and forms of public administration are divided into general and special.

With this understanding of the subject of administrative law, each set of administrative legal relations clearly ranks deterministic specific legal grounds place.

Relations accountability of public administration are derived from relationships appeal of actions that can be done, first, out of court (filing an administrative complaint); Second, the court - by an appeal against the Administrative Court (judicial review).

In the second case (appeal against the Administrative Court) there are relations of administrative proceedings.

Filing complaints with the court (court of appeal) is proved by administrative justice, which is a form of justice. An external expression of Administrative Procedure is the activity of administrative courts to review and resolve public disputes between the parties in public law relationships, where relationships in every party are the executive body of local government or other public authorities.

In the area of judicial appeal relations, referred to the administrative court disputes are called "administrative matters" or "administrative jurisdiction of the case". According to the Administrative Code of Ukraine, the right of administrative jurisdiction (or administrative), it is - referred to the administrative court of public dispute in which at least one party is an executive agency, local government, their official or official or other subjects 'object that performs power management functions on the basis of legislation, including the delegated powers. Those cases are violated by an administrative claim. The plaintiff in an administrative case can be citizen of Ukraine, foreigner or stateless person, enterprises, institutions, organizations (legal entities), public authorities. The defendant in the case is an administrative authority, unless otherwise provided by the Administrative Code of Ukraine.

Systemic understanding of administrative justice provides the establishment of its place not only in the subject of administrative law. Important theoretical importance 
is the question of his relationship with the totality of the administrative and procedural forms that form the concept of "administrative process".

Today the idea that the administrative process is merely procedural activity of administrative courts is spreading. It is based on the formula of "administrative process - relationship, consisting in the implementation of administrative justice" (Administrative Code of Ukraine, Art. 3 "Definitions"). However, the same article contains the following warning: "This Code, the following terms have the following meanings $<\ldots>$ ". It follows that defined in Art. 3 terms (including the definition of the administrative process) is conclusive only in administrative proceedings.

\section{Conclusion}

Analysis of the current regulatory material evidence of the use of the term "process" to others (except for administrative justice) types of administrative relations. This, for example, is the process of determining the level of danger of the investigation (regarding aviation accidents and incidents), the process of regulation of aviation, the budget process.

This does not give grounds to believe that the legislator establishes a monopoly on the use of administrative justice and the concept of the term "administrative process" and its use on the territory of other administrative and legal space is fair.

Accordingly, the actual definition of the administrative process is a generic name of legal regulated public administration to implement the power. This activity is carried out in the areas generated by monogenic relations and objects as structural components of the subject of administrative law.

\section{Bibliography:}

1. Відомості Верховної Ради України. 1997. № 40. Ст. 263.

2. Відомості Верховної Ради України. 2005. № 35-37. Ст. 446.

3. Авер'янов В.Б. Адміністративне право України: доктринальні аспекти реформування. Право України. 1998. № 8. С. 8-13.

4. Колпаков В.К. Адміністративне право України: підручник. К.: Юрінком Інтер, 1999. $736 \mathrm{c}$.

5. Ямпольская Ц.А. О месте административного права в системе советского социалистического права. Советское государство и право. 1956. № 9. С. 98-102.

6. О системе советского социалистического права (обзор). Советское государство и право. 1958. № 1. С. 101-108.

7. Петров Г.И. Сущность советского административного права. Л.: ЛГУ, 1959. 185 с.

8. Погорілко В.Ф. Публічна влада. Юридична енциклопедія: в 6 т. / за ред. Ю.С. Шемшученка. К.: Укр. енциклопедія, 2003. Т. 5.736 с.

9. Колпаков В.К. Предмет адміністративного права: сучасний вимір. Юридична Україна. 2008. № 3. С. 33-38.

10. Kolpakov V.K. Legal nature of the administrative tort law of Ukraine. Yearbook of Ukrainian law: coll. of scientific papers / responsible for the issue O.V. Petryshyn. Kharkiv: Law, 2017. № 9. P. 111-118.

\section{References:}

1. Vidomosti Verkhovnoi Rady Ukrainy (1997). no 40, art. 263

2. Vidomosti Verkhovnoi Rady Ukrainy (2005). no. 35-37, art. 446. 
3. Averianov, V.B. (1998). Administratyvne pravo Ukrainy: doktrynalni aspekty reformuvannia [Administrative law of Ukraine: doctrinal aspects of reforming]. Pravo Ukrainy, no. 8, pp. 8-13.

4. Kolpakov, V.K. (1999). Administratyvne pravo Ukrainy: pidruchnyk [Administrative law of Ukraine: textbook]. Kyiv: Yurinkom Inter. [in Ukrainian]

5. Yampol'skaya, Ts.A. (1956). O meste administrativnogo prava $\mathrm{v}$ sisteme sovetskogo sotsialisticheskogo prava [On the place of administrative law in the system of Soviet socialist law]. Sovetskoe gosudarstvo i pravo, no. 9, pp. 98-102.

6. Sovetskoe gosudarstvo i pravo (1958). O sisteme sovetskogo sotsialisticheskogo prava (obzor) [On the system of Soviet socialist law (review)]. Sovetskoe gosudarstvo i pravo, no. 1, pp. 101-108.

7. Petrov, G.I. (1959). Sushchnost' sovetskogo administrativnogo prava [The essence of Soviet administrative law]. Lviv: LGU. [in Russian]

8. Pohorilko, V.F. (2003). Publichna vlada [Public authority]. Yurydychna entsyklopediia: v 6 t. (eds. Yu.S. Shemshuchenko etc.). vol. 5. Kyiv: Ukr. entsyklopediia. [in Ukrainian]

9. Kolpakov, V.K. (2008). Predmet administratyvnoho prava: suchasnyi vymir [The subject of administrative law: modern dimension]. Yurydychna Ukraina, no. 3, pp. 33-38.

10. Kolpakov, V.K. (2017). Legal nature of the administrative tort law of Ukraine. Yearbook of Ukrainian law: Coll. of scientific papers / responsible for the issue O.V. Petryshyn. Kharkiv: Law, no. 9, pp. 111-118.

\section{АДМІНІСТРАТИВНО-ПРОЦЕСУАЛЬНІ ВІДНОСИНИ В МЕЖАХ АДМІНІСТРАТИВНОГО ПРАВА}

\section{Колпаков Валерій Костянтинович,} завідувач кафедри адміністративного та цивільного права Запорізького національного університету, доктор юридичних наук, професор

У статті досліджено адміністративно-процесуальні відносини, які існують y сфері діяльності адміністративних судів. Їх місие встановлює відносини в адміністративному праві України. Тому автор досліджує правову природу норм адміністративного судочинства; аналізуе законодавство про адміністративні суди; розглядає практику роботи адміністративних судів; вивчає історію адміністративної судової системи; аналізуе наукові дослідження у сфері адміністративного права, адміністративного процесу, функиіонування судової системи; вивчає проекти нормативних документів у сфері адміністративного судочинства. У результаті дослідження автор запропонував визначення адміністративно-процесуальних відносин.

Ключові слова: адміністративний суд, адміністративна юрисдикція, адміністративне право, адміністративне судочинство, адміністративний процес, процесуальні відносини, державне управління. 